\title{
Incidence, Histological Types and Age at Presentation of Borderline and Malignant Ovarian Tumors at a Tertiary Institute in Nepal
}

\author{
Bista KDB \\ Deptartment of Obstetrics and Gynecology, Tribhuvan University Teaching Hospital, Kathmandu, Nepal
}

Received: April 10, 2014; Accepted: October 18, 2014

\begin{abstract}
Aims: The objective of this study was to find the incidence, assess the age and stage of presentation of ovarian malignancy and correlate these features with the histological types.

Methods: Retrospective analysis of ovarian tumor cases that underwent primary surgery at our institute between April 2009 - April 2012 was done. Age, histological type, stage of the disease features were analyzed. Statistical analysis was done by Chi square and $\mathrm{T}$ test.

Results: Out of 451 ovarian tumor cases, 81 cases of borderline and malignant ovarian tumor were seen. Germ cell tumors were the most common type of ovarian tumors. The mean age of presentation of primary malignant tumors was 41.9 years. Serous adenocarcinoma was the most common ovarian cancer occurring in $22.2 \%(n=67)$ cases. In women $<40$ years the likelihood of germ cell cancer was significantly more than non germ cell malignancies ( $p$ value $<0.001$ ). Epithelial ovarian malignancies were more likely to present at late stages than non-epithelail malignancies and this was found to be statistically significant with $\mathrm{p}$ value of 0.003 . Increasing age was associated with increasing stage of cancer.
\end{abstract}

Conclusions: Germ cell tumors were the most common ovarian tumors, but epithelial tumors were the most common malignant ovarian tumors. Increasing age was associated with increasing stage of disease.

Keywords: epithelial; germcell; ovarian malignancy.

\section{INTRODUCTION}

The importance of ovarian cancer lies in the fact that it presents at very late stage, and therefore carries a poor prognosis. According to the Center for Disease Control about 20000 women get ovarian cancer every year. It is the eighth commonest female malignancy in the US and it causes more deaths than any other cancer of the female genital tract. ${ }^{1}$ The Brazilian National Institute of Cancer describes epithelial ovarian cancer as a high mortality gynecological cancer. ${ }^{2}$ According to the IARC Globocan 2012 data, the incidence of ovarian cancer is $3.6 \%$ behind breast, colorectal, cervix, lung, uterine and stomach cancer. ${ }^{1}$

At Tribhuvan University Teaching Hospital based on hospital audit data, ovarian tumors are the most

\section{CORRESPONDENCE}

Dr Kesang D B Bista

Department of Obstetrics and Gynaecology,

Tribhuvan University Teaching Hospital,

Kathmandu, Nepal.

Email: kesangdikibista@hotmail.com

Phone: +977- 9851046926 common type of genital malignancy and also the most common to undergo surgery. This case series was therefore done to assess the different histopathological types of borderline and malignant ovarian cancer cases that presented to our hospital and correlate them with age. This is the first study to assess only borderline and malignant ovarian tumors in our population.

\section{METHODS}

This was a retrospective analysis of all malignant ovarian cancer cases, who underwent primary surgery at Tribhuvan University Teaching Hospital over a period of three years between April 2009- April 2012. All case sheets were analyzed regarding patient age, histopathology and stage of disease. Histopathological diagnosis was retrieved from the department of pathology. WHO classification of ovarian tumor was used. Stage I and II were considered as early stage disease and stage III and IV as late stage disease. Approval from ethical committee was taken for 
the study. Data has been presented in means and percentages. Statistical analysis was done using Chi square and $\mathrm{T}$ test wherever needed and $\mathrm{p}$-value less than 0.05 was taken as significant.
Out of the total 451 cases, 81 cases of borderline and malignant ovarian tumor were taken into the study. Benign tumors were the most common constituting $82 \%$ of all ovarian tumors. Germ cell tumors were the most common type of ovarian tumors in this study.

\section{RESULTS}

Table 1. Total ovarian tumor cases $(n=451)$.

\begin{tabular}{|lllllll|}
\hline & Epithelial & Germ cell & Stromal & Others & Metastatic & Total (\%) \\
Benign & 151 & 215 & 4 & - & - & $370(82 \%)$ \\
Borderline & 14 & - & - & - & - & $14(3.1 \%)$ \\
Malignant & 38 & 15 & 4 & 2 & 8 & $67(14.9 \%)$ \\
& $203(45 \%)$ & $230(51 \%)$ & $8(1.8 \%)$ & $2(0.4 \%)$ & $8(1.8 \%)$ & 451 \\
\hline
\end{tabular}

Table 2. Histological distribution of borderline and malignant ovarian tumors $(n=81)$.

Types

A.

Serous adenocarcinoma

Borderline serousadenoma

Mucinous adenocarcinoma

Borderline Mucinous adenoma

Endometroid adenocarcinoma

Clear cell adenocarcinoma

Transitional cell carcinoma

Undifferentiated adenocarcinoma

Malignant mixed mesodermal tumor

\section{B. Germ cell type}

Dysgerminoma

Yolk sac tumor

Mixed germcell tumor

Immature Teratoma

Malignancy in dermoid

C. Stromal Tumors

Granulosa cell tumor

Fibrosarcoma

D. Metastatic

E. Others: lymphoma

\section{Number}

\section{2}

18

4

8

10

4

3

1

2

2

15

4

3

3

2

3

4

3

1

8

2
$\%$

$64.2 \%$

$22.2 \%$

$4.9 \%$

$9.9 \%$

$12.3 \%$

$4.9 \%$

$3.7 \%$

$1.2 \%$

$2.5 \%$

$2.5 \%$

$18.5 \%$

$4.9 \%$

$3.7 \%$

$3.7 \%$

$2.5 \%$

$3.7 \%$

$4.9 \%$

$3.7 \%$

$1.2 \%$

9.9\%

$2.5 \%$ 


\begin{tabular}{|c|c|c|c|c|c|c|c|}
\hline Age & $\begin{array}{l}\text { Epithelial } \\
\text { malignant }\end{array}$ & $\begin{array}{l}\text { Borderline } \\
\text { Epithelial }\end{array}$ & Germ cell & Stromal & Metastatic & Others & Total \\
\hline Mean age & 49. $6 \mathrm{yrs}$ & $44.1 \mathrm{yrs}$ & $22.3 \mathrm{yrs}$ & $53 \mathrm{yrs}$ & $50.1 \mathrm{yrs}$ & $11.5 \mathrm{yrs}$ & \\
\hline$<20$ & - & 1 & 9 & - & & 2 & $\begin{array}{l}12 \\
(14.8 \%)\end{array}$ \\
\hline $21-40$ & 8 & 5 & 3 & - & 2 & - & $18(22.2 \%)$ \\
\hline $41-60$ & 23 & 6 & 3 & 3 & 5 & - & $\begin{array}{l}40 \\
(49.4 \%)\end{array}$ \\
\hline \multirow[t]{2}{*}{$>60$} & 7 & 2 & - & 1 & 1 & - & $\begin{array}{l}11 \\
(13.6 \%)\end{array}$ \\
\hline & $\begin{array}{l}38 \\
(46.9 \%)\end{array}$ & $\begin{array}{l}14 \\
(17.3 \%)\end{array}$ & $\begin{array}{l}15 \\
(18.5 \%)\end{array}$ & $\begin{array}{l}4 \\
(4.9 \%)\end{array}$ & $\begin{array}{l}8 \\
(9.9 \%)\end{array}$ & $\begin{array}{l}2 \\
(2.5 \%)\end{array}$ & $\begin{array}{l}81 \\
(100 \%)\end{array}$ \\
\hline
\end{tabular}

Thirty cases (37\%) were seen in women younger than 40 years of age, of which $12(40 \%)$ were of germ cell type, $8(26.7 \%)$ epithelial malignancy, 7 (23.3\%) borderline, $1(3.3 \%)$ metastatic and $2(6.7 \%)$ were lymphoma cases. In women $<40$ years the likelihood of germ cell cancer was significantly more thannon germ cell malignancies, and this was found to be statistically significant with $p$ value $<0.001$.

\begin{tabular}{|llllllll|}
\hline \multicolumn{7}{|l|}{ Table 4. Correlation between age and epithelial malignancy types $(\mathrm{n}=\mathbf{3 8})$. } \\
\hline Age & $\begin{array}{l}\text { Serous } \\
\mathbf{n = 1 8}\end{array}$ & $\begin{array}{l}\text { Mucinous } \\
\mathbf{n = 8}\end{array}$ & $\begin{array}{l}\text { Endometroid } \\
\mathbf{n}=\mathbf{4}\end{array}$ & $\begin{array}{l}\text { Clear cell } \\
\mathbf{n}=\mathbf{3}\end{array}$ & $\begin{array}{l}\text { Transitional } \\
\mathbf{n}=\mathbf{1}\end{array}$ & $\begin{array}{l}\text { Others } \\
\mathbf{n}=\mathbf{4}\end{array}$ & Total \\
Mean age & $56.7 \mathrm{yrs}$ & $38.4 \mathrm{yrs}$ & $46.3 \mathrm{yrs}$ & $46 \mathrm{yrs}$ & $44 \mathrm{yrs}$ & $47.5 \mathrm{yrs}$ & 49.6 years \\
$0-20$ & - & - & - & - & - & - & 0 \\
$21-40$ & 1 & 6 & - & - & - & 1 & $8(21.1 \%)$ \\
$41-60$ & 11 & 1 & 4 & 3 & 1 & 3 & 23 \\
$>60 \mathrm{yrs}$ & 6 & 1 & - & - & - & - & $7(18.4 \%)$ \\
Total & 18 & 8 & 4 & 3 & 1 & 4 & 38 \\
\hline
\end{tabular}

In the germ cell tumor group 12/15 (80\%) were in the age group less than 40 . Three of the cases ie $20 \%$ were $>40$ years and all were mature cystic teratoma with a malignant component. Of the primary malignant ovarian tumor cases $29(50.9 \%)$ came in stage I, $3(5.2 \%)$ in stage II, $24(42.1 \%)$ in stage III and $1(1.8 \%)$ in stage IV. Epithelial ovarian malignancies were more likely to present at late stages than non-epithelial malignancies and this was statistically significant with $p$ value of 0.003 . Of the 14 borderline epithelial ovarian tumor cases 13 (93\%) were in stage I. There was only one case of mucinous borderline tumor with stage III disease with positive peritoneal deposits. Germ cell and stromal cell cancers accounted for about $55 \%$ of stage I disease, whereas epithelial ovarian cancers accounted for $91 \%$ of stage III disease. Among the primary malignant ovarian cancer cases excluding borderline epithelial tumors, correlation between age at presentation and stage of disease was assessed. Mean age at presentation of primary ovarian tumor was 41.9 years. Age at presentation for stage I was 33.8 years, 39 years for stage II, 53.7 years for stage III and 41 years for stage IV cases. Early stage disease was seen in younger age group (36.5 years) compared to late stage presentation in older age group (47.4 years) and this was found to be statistically significant with $\mathrm{p}$ value $<0.001$. Therefore it was noted that age was 
increasing with stage of disease. Borderline epithelial ovarian tumors presented at mean age of 44.1 years and $13 / 14(93 \%)$ had stage I disease.

\begin{tabular}{|c|c|c|c|c|c|}
\hline Institute, year & $\begin{array}{l}\text { Total cases } \\
\text { studied }\end{array}$ & Benign & Malignant & Borderline & $\begin{array}{l}\text { Epithelial/germ } \\
\text { cell (total) }\end{array}$ \\
\hline $\begin{array}{l}\text { Tribhuvan University } \\
\text { Teaching Hospital, } 2008\end{array}$ & 161 & 135 & $26(16 \%)$ & - & $52.2 \% / 42.2 \%$ \\
\hline $\begin{array}{l}\text { Nepal Medical College, } \\
2009\end{array}$ & 95 & 86 & $9(9.5 \%)$ & - & $72.6 \% / 27.4 \%$ \\
\hline $\begin{array}{l}\text { Kathmandu Medical } \\
\text { College, } 2011\end{array}$ & 102 & 89 & $13(12.7 \%)$ & - & $69.5 \% / 19.5 \%$ \\
\hline BPKIHS, 2012 & 83 & 66 & $15(18 \%)$ & $2(2.4 \%)$ & $47 \% / 45 \%$ \\
\hline $\begin{array}{l}\text { Birendra Army Hospital, } \\
2011\end{array}$ & 100 & 68 & $29(29 \%)$ & $3(3 \%)$ & $56 \% / 35 \%$ \\
\hline Total & 541 & $444(82 \%)$ & $92(17 \%)$ & $5(2.7 \%)$ & $59.5 \% / 33.8 \%$ \\
\hline
\end{tabular}

\section{DISCUSSION}

\section{Incidence of malignancy/borderline tumors}

Benign ovarian tumors were the most common type $82 \%(n=370)$ with malignant ovarian tumors accounting for $15 \%$ and borderline ovarian tumors consisting of $3 \%$ of the total cases. Table 5 shows the studies done in other institutions in Nepal where the incidence of malignant ovarian tumor ranges from $10-29 \% 0^{3-6}$ Study done by Mondal et $\mathrm{al}^{7}$ showed that benign tumors constituted $63 \%$, malignant $29.6 \%$ and borderline tumors $7.3 \%$. Other studies by Gupta, ${ }^{8}$ Malli, ${ }^{9}$ Bukhari $^{10}$ and Iyoke ${ }^{11}$ also showed slightly higher malignancy rates $22.9 \%, 27 \%, 20 \%$ and $25 \%$ respectively. But there are studies which have shown even higher incidence of malignancy cases ranging from $31-40.8 \% .{ }^{12-14}$ This could be explained by the larger referrals to specialized centres which results in higher malignancy rates while simple lesions are managed in general hospitals. Also geographical variations may be playing a role but this still needs to be studied. The incidence of borderline cases as reported in this study was 3\% which is similar to other studies done in Nepal which has shown range between $2.4-3 \%{ }^{15}$ Higher rates of $20 \%$ incidence of borderline tumors have also been reported by Rettenmaier et al. ${ }^{16}$

\section{Histological types of ovarian tumor}

Germ cell ovarian tumors were the most common type of ovarian tumor in this study accounting for
$51 \%$ of all tumors followed by epithelial ovarian tumors at $45 \%$. In a study done at same institute 4 years back, the incidence of epithelial and germ cell tumors were $52 \%$ and $42 \%$ respectively. ${ }^{3}$ The high incidence of germ cell tumor in general, is mainly due to the high incidence of dermoid cyst compared to other tumors of the ovary in this institute. Few studies in Africa have also found germ cell tumors as the most common overall ovarian tumor. ${ }^{17}$ In most other studies epithelial ovarian tumors are the commonest. The average incidence of epithelial and germ cell tumor among other studies ${ }^{7,18}$ from Nepal is $59 \%$ and $33 \%$ respectively. This is in contrast to the present study. Another reason could be due to more referrals of germcell tumors in very young girls, as ours is a tertiary level institute. About $75 \%$ of the malignancies in women $<20$ years, in the present study were germ cell type. Although germ cell tumors were the most common ovarian tumors, among malignant cases epithelial ovarian tumors were the most common malignancy in this study (Table 2). Studies done in Nepal show that epithelial malignancy ranges from $40-69 \%$ whereas germ cell malignancy rates range from $11.5-33 \% .{ }^{7,18}$ This is in keeping with most other studies where epithelial tumors are still the most common malignant ovarian tumor. Mondal et $\mathrm{al}^{7}$ in his study also found that epithelial tumors comprised $67 \%$ of all tumors and $60.9 \%$ of malignant 
tumors. Among the malignant epithelial tumors, serous adenocarcinoma was the commonest at $22 \%$ followed by $10 \%$ cases of mucinous adenocarcinoma. Most of studies done in Nepal show serous adenocarcinoma as the most common malignancy (Table 5). Studies done in Central Africa also show serous adenocarcinoma as the most common ovarian malignancy ie $36 \%$, followed by $24 \%$ cases of mucinous adenocarcinoma. ${ }^{11}$ Studies done in India and Pakistan also show that serous adenocarcinomas are the most common type ranging from $11-20 \%$ cases. $^{7,8,10,19}$ Studies done in Brazil show that serous adenocarcinoma account for $30 \%$ of cases, and $13.7 \%$ cases of mucinous adenocarcinomas and endometroid adenocarcinomas each. ${ }^{1}$

Few studies in developed countries have shown that endometroid adenocarcinomas account for the second most common epithelial malignancy. ${ }^{16}$ This is not the case with this study and in other Indian and Asian studies, where mucinous adenocarcinomas are more common than endometroid adenocarcinomas. ${ }^{7-10}$ Metastatic tumors constituted about $10 \%$ of cases too and this could be due to the multidisciplinary tertiary level of this institute which leads to more varied, referred cases from outside or from other departments mainly surgical. Metastatic tumors in other studies from Nepal range from $6.9 \%$ to $20 \%$ with gastrointestinal sites being the most common primary site, as was in this study. ${ }^{6,7,17}$

\section{Correlation of age with malignant ovarian tumors}

According to the American Cancer Society, half of the women with ovarian malignancy are 63 years and older. The mean age for primary malignant ovarian tumors in this study was 41.9 years and slightly more at 49.6 years for malignant epithelial ovarian cancers. Although the incidence of epithelial ovarian malignancy begins from the age of 40 years, the largest number of ovarian cancer cases are being found in the $60-65$ years age group. ${ }^{20}$ Scully also reports that malignant epithelial ovarian cancer peak incidence is between 56-60 years. ${ }^{21}$ The Age Specific Incidence Rate (ASIR) for ovarian cancer in a study done in India by Murthi et al, ${ }^{22}$ revealed that the disease increases from 35 years of age and reaches a peak between the ages 55-64. In the study by Mondal et $\mathrm{al}^{7}$ in Eastern India the mean age of ovarian malignancy cases was 49 years which is slightly higher than in this study. Study done in Nigeria, has also shown that the average age for ovarian malignancy was 45.4 years. ${ }^{11}$ This study shows a slightly lower age at presentation of

ovarian cancers especially epithelial type ie $<50$ years in this study population which is also seen in certain African and Asian countries. The exact cause or risk factors in these patients thus needs to be further studied. Another factor that increases the rate of ovarian cancer in young women are the germ cell tumors. The average age at diagnosis of germ cell malignancies was 22 years in this study and this has been seen universally. In this study there were eight cases (12\% of malignant ovarian cancer cases), with $\leq 15$ years of age. These were of germ cell origin along with a lymphoma case, which could have resulted in lower mean age for ovarian malignancies. Another important correlation with age that has been seen is that, increasing age was associated with increasing stage of disease. Paes et $\mathrm{al}^{2}$ in their study also found that age at diagnosis was statistically significant between the group of better prognosis (48.90 yrs \pm $11.74)$ and the group of poorest prognosis disease (57.90 years \pm 13.52 ). Therefore it would seem that no age seems to be spared. The younger mean age at presentation of ovarian malignancies is an important finding from this study, which will help increase awareness of such tumors even in younger women. Screening and education efforts can also be directed at an early age in the population. This would aid in early diagnosis and therefore better prognosis.

\section{CONCLUSIONS}

Germ cell tumors were the most common type of ovarian tumor, although epithelial type was the most common malignancy. Serous adenocarcinoma was the most common ovarian malignancy. Mean age of primary malignant ovarian tumor was 41.9 years. Age group was significantly younger in germ cell malignancies. Epithelial ovarian malignancy presented mainly in late stage whereas germ cell, stromal and borderline epithelial cases presented at an early stage. 


\section{DISCLOSURE}

The authors report no conflicts of interest in this work.

No violation of human rights and safety.

Funding: Nil

\section{REFERENCES}

1. WHO, Globocan 2012. Estimated cancer incidence, mortality and prevalence worldwide in 2012. Lyon: IARC Publication; 2012.

2. Paes MF, Daltoé DR, Madeira KP, Rezende LCD, Sirtoli GM, Herlinger AL, et al. A retrospective analysis of clinicopathological and prognostic characteristics of ovarian tumors in the State of Espírito Santo, Brazil. Journal of Ovarian Research. 2011;4:14-9.

3. Jha R, Karki S. Histological pattern of ovarian tumors and their age distribution. Nepal Med Coll J. 2008;10:81-5.

4. Kayastha S. Study of ovarian tumors in Nepal Medical College Teaching Hospital. Nepal Med Coll J. 2009;11:200-2.

5. Khatri R. Clinicopathological analysis of ovarian tumors at Birendra Military Hospital. Medical J Shree Birendra Hospital. 2010;10:26-31

6. Pudasaini S, Lakhey M, Hirachand S, Akhter J, Thapa B. A study of ovarian cyst in a tertiary hospital of Kathmandu valley. Nepal Med Coll J. 2011;13(1):39-41.

7. Mondal SK, Banyopadhyay R, Nag DR, Roychowdhury S, Mondal PK, Sinha SK. Histologic pattern, bilaterality and clinical evaluation of 957 ovarian neoplasms: a 10-year study in a tertiary hospital of eastern India. J Can Res Ther 2011;7:433-7.

8. Gupta N, Bisht D, Agarwal AK, Sharma VK. Retrospective and prospective study of ovarian tumours and tumour-like lesions. Indian J Pathol Microbiol. 2007;50:525-7.

9. Malli M, Vyas B, Gupta S, Desai H. A histological study of ovarian tumors in different age groups. Int J Med Sci Public Health. 2014;3:338-41.

10. Bukhari U, Memon Q, Memon H. Frequency and pattern of ovarian tumours. Pak J Med Sci. 2011;27:884-6.

11. Iyoke CA, Ifeadike CO, Nnebue CC, Nkwo PO, Ezugwu EC, Edosuyi L, et al. A ten-year review of ovarian cancer in Enugu, south east Nigeria. Afrimedic Journal. 2011;2(1):8-12

12. Mukherjee C, Dasgupta A, Ghosh RN, Sengupta J. Ovarian tumours a ten years study. J Obstet Gynaecol India. 1991;41:691-6.
13. Muhammad A, Makaju R. Retrospective histopathological analysis of ovarian neoplasms of the female reproductive system seen at Kathmandu University Teaching Hospital, Dhulikhel, Nepal. Kathmandu University Med J. 2006;4(1):48-53.

14. Ahmed Z, Kayani N, Hasan SH, Muzaffar S, Gill MS. Histological pattern of ovarian neoplasms. J Pak Med Assoc. 2000;50:416-19.

15. Thanikasalam K, Ho CM, Adeed N, Shahidan MN, Azizah WK. Pattern of ovarian tumors among Malaysian women at general hospital, Kuala Lumpur. Med J Malaysia. 1992;47(2):139-46

16. Rettenmaier MA, Lopez K, Abaid LN, Brown JV, Micha JP, Goldstein BH. Borderline ovarian tumors and extended patient followup: an individual institutions experience. J Surg Oncol. 2010;101:18-21.

17. Onyiaorah IV, Anunobi CC, Banjo AA, Fatima AA, Nwankwo KC. Histopathological patterns of ovarian tumours seen in Lagos University Teaching Hospital: a ten-year retrospective study. Nig Q J Hosp Med. 2011;21(2):114-8.

18. Pradhan A, Upreti D, Sinha AK. Patterns of ovarian tumors at BPKIHS. Health Renaissance. 2012;10:87-97.

19. Shoail I, Hayat Z, Saeed S. A comparative analysis of frequency and patterns of ovarian tumours at a tertiary care hospital between two different study periods (2002-2009). J Postgrad Med Inst. 2012;26(2):196-200.

20. Di Sai PJ, Creasman WT, editors. Clinical Gynecology Oncology. 6th ed. Phildelphia: Mosby; 2002.

21. Scully RE, Young RH, Clement PB. Atlas of tumor pathology. Tumors of the ovary, maldeveloped gonads, fallopian tube and broad ligament. 3rd series, Fascicle 23. Armed Force Institute of Pathology; 1999.

22. Murthy NS, Shalini S, Suman G, Pruthvish S, Mathew A. Changing trends in incidence of ovarian cancer- the Indian scenario. Asian Pac J Cancer Prev. 2009;10:1025-30. 